\title{
Clinical Stage 0 Esophageal Adenocarcinoma AJCC v8
}

National Cancer Institute

\section{Source}

National Cancer Institute. Clinical Stage O Esophageal Adenocarcinoma A/CC v8. NCI

Thesaurus. Code C133402.

Stage 0 includes: T is, NO, MO. Tis: High-grade dysplasia, defined as malignant cells confined to the epithelium by the basement membrane. N0: No regional lymph node metastasis. M0: No distant metastasis. (AJCC 8th ed.) 